\title{
Mitochondrial variation among Australian freshwater turtles (genus Myuchelys), with special reference to the Endangered $M$. bellii
}

\author{
Darren Fielder $^{1, *}$, Karl Vernes ${ }^{1}$, Erika Alacs ${ }^{2}$, Arthur Georges ${ }^{2}$ \\ ${ }^{1}$ Ecosystem Management, University of New England, Armidale, New South Wales 2351, Australia \\ ${ }^{2}$ Institute for Applied Ecology, University of Canberra, Australian Capital Territory 2601, Australia
}

\begin{abstract}
Identifying species and the relationships among them remains important for assessing biodiversity trends and is a critical focus for reversing global biodiversity loss. The saw-shelled turtles of Australia, in the genus Myuchelys, show cryptic diversity and include species that range from Endangered $(M$. bellii), through those that are locally abundant but extremely limited in distribution ( $M$. georgesi and $M$. purvisi) to those that are common and widespread ( $M$. latisternum). The Endangered $M$. bellii is restricted to 3 small isolated populations in the headwaters of the Murray-Darling basin, in the Border, Gwydir and Namoi tributaries. There is no evidence of strong differentiation among these 3 populations based on mitochondrial DNA (mtDNA) divergences; rather there is only a shallow genetic structure ranging from 0.1 to $0.3 \%$ divergence. The 3 restricted and small populations of the Endangered $M$. bellii face a number of threatening processes and require conservation management across state boundaries as a single biological species. The mtDNA phylogeny supports previous phylogenetic findings of a deep phylogenetic divergence between $M$. purvisi and $M$. georgesi (13.5\% mtDNA) and the sister taxa relationship of $M$. latisternum and $M$. bellii. A notable exception was our finding that Emydura macquarii and M. georgesi are sister taxa inside the Myuchelys radiation.
\end{abstract}

KEY WORDS: Emydura macquarii - Myuchelys georgesi - Elseya $\cdot$ Chelidae $\cdot$ Freshwater turtles · Cryptic species

\section{INTRODUCTION}

Biodiversity loss is of increasing concern to governments nationally and internationally. A substantial array of legislative and regulatory systems are in place to protect it, recognising the value the community places on biodiversity for the services it delivers in maintaining the quality of the air we breathe, the water we drink and the food we eat (Cairns 1997, Salzman 1998, Baumgärtner 2007, Anderson et al. 2009). While these legislative instruments recognise biodiversity at a range of levels, the central focus of biological conservation is at the species level, so identifying species, and relationships among species, remains a core focus of managers aiming to preserve biodiversity. For example, international systems of biodiversity protection such as the International Union for Conservation of Nature (IUCN) Red List and national systems such as the United Kingdom Endangered Species Act, United States Endangered Species Act and the Australian Environment Protection and Biodiversity Conservation Act (EPBC Act) rely on good taxonomic knowledge at the species level. However, because such knowledge is often incomplete, conservation action can be misguided or misdirected (Roman et al. 1999, Engstrom et al. 2004, Georges et al. 2011). 
Recent developments in molecular approaches to describe species genetic makeup have accelerated progress in documenting biodiversity and have revealed an unexpected level of cryptic biodiversity. For example, the Asian leaf turtle Cyclemys dentata was regarded as a single widespread polytypic species until molecular and morphological analysis revealed a species complex of several formerly cryptic species (Fritz et al. 2008, Stuart \& Fritz 2008). The Endangered giant narrow-headed softshell turtle Chitra indica is also likely to be a species complex, as mitochondrial $\mathrm{NADH}$ dehydrogenase subunit 4 sequences reveal 3 deeply divergent, monophyletic lineages (Engstrom et al. 2002). Similarly, the European pond turtle Emys obicularis contains a cryptic species endemic to Sicily (Fritz et al. 2005, 2006). The Sicilian form, E. trinacris, is highly distinct genetically while morphologically resembling E. obicularis galloitalica (Fritz et al. 2005).

Failure to recognise underlying cryptic diversity at or below the level of species can have a great influence on biological conservation outcomes, either through declines in cryptic species that go undetected and as a result are poorly managed (as with Cyclemys; Fritz et al. 2008, Stuart \& Fritz 2008) or because diversity that is suspected but with poor foundation leads to misallocation of resources (Georges et al. 2011). In addition, phylogenetic information has a role to play in assessing distinctiveness, an attribute that has an influence on determining conservation priorities (Faith 1992, Moritz 1995).

The saw-shelled turtles of Australia, in the genus Myuchelys, show cryptic diversity where species are morphologically conserved including suspected taxa within currently accepted species. The genus Myuchelys (formerly Elseya latisternum clade) was recently separated from the genus Elseya to account for the paraphyletic arrangement with respect to Emydura (Thomson \& Georges 2009, Georges \& Thomson 2010). The genus includes species that range from Endangered ( $M$. bellii), through to those that are locally abundant but extremely limited in distribution ( $M$. georgesi and $M$. purvisi) to those that are common and widespread (M. latisternum) (Fig. 1). M. bellii is of particular interest because it is restricted to 3 small isolated populations in the headwaters of the Murray-Darling basin, in the Border, Gwydir and
Namoi tributaries. As such, the species is listed as Endangered in the IUCN Red Data Book (IUCN 2011) and vulnerable by the Australian authorities at State (Threatened Species Conservation Act, New South Wales 1995) and national level (EPBC Act, Commonwealth of Australia 1999). Suggestions that the populations in Girraween National Park of Queensland are sufficiently distinct to warrant recognition at species or subspecies level (Cann 1998, Wells 2002) is of particular interest to conservation agencies. (Note that Wells 2002 is not regarded as a publication for nomenclatural purposes. Refer to Georges \& Thomson 2010.)

Multilocus allozyme studies (Georges \& Adams 1992) revealed that Myuchelys georgesi and $M$. purvisi were deeply divergent genetically, although remarkably similar morphologically differing only in the presence or absence of neural bones in the carapace (Thomson \& Georges 1996). They were regarded as the same taxon until $M$. georgesi was formally described by Cann (1997). Furthermore, they are not sister taxa, as the accompanying phylogenetic analysis by Georges \& Adams (1992, 1996) revealed that their common ancestor had $M$. latisternum and $M$. bellii among its descendants. Recent taxonomic revisions (Thomson \& Georges 2009, Georges \& Thomson 2010) based on the earlier phylogenetic analysis place Emydura between Elseya and Myuchelys. These relationships have often been

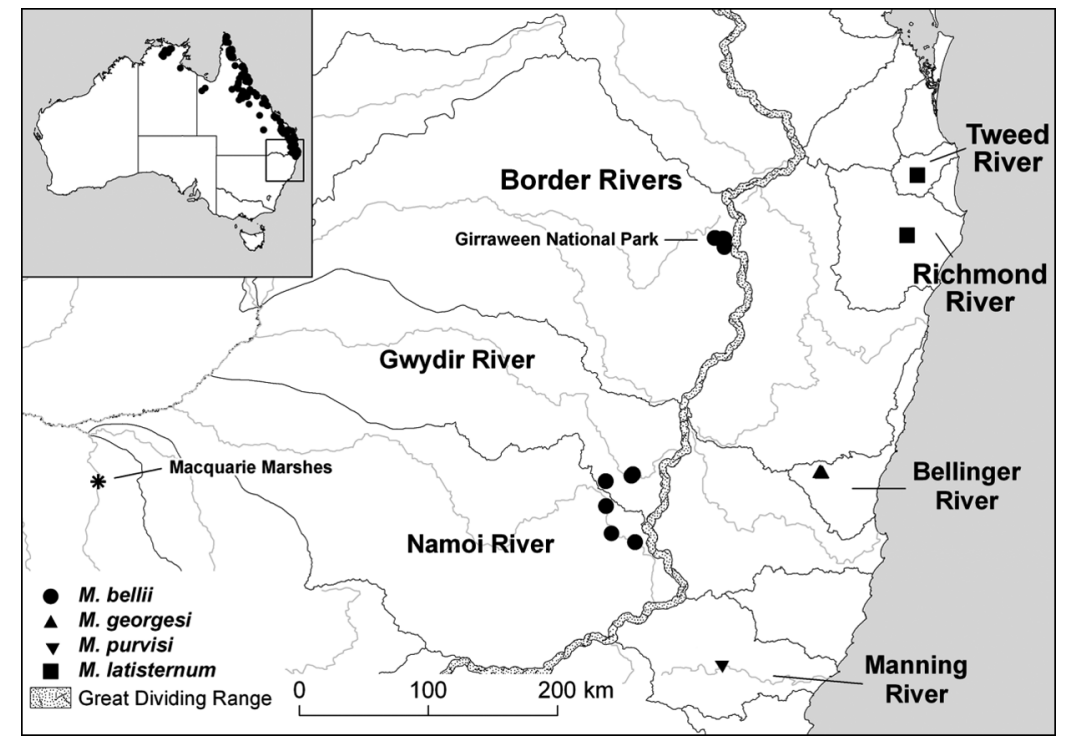

Fig. 1. Myuchelys spp. Capture localities of the Myuchelys specimens used for mtDNA sequencing. Macquarie Marshes and Girraween National Park (Bald Rock Creek) are also shown. Drainage basin names are those of Australia's River Basins 1997 available from Geoscience Australia. Inset depicts the distribution of $M$. latisternum from coastal catchments of northern New South Wales, eastern Queensland and the Northern Territory of Australia 
contested in past taxonomic studies using morphology or genetic markers (Gaffney 1977, Legler \& Cann 1980, McDowell 1983, Thomson \& Georges 2009). Notwithstanding limitations of single locus markers, such as mtDNA, in species boundary studies, we examined mtDNA variation across the genus Myuchelys to determine whether the signal there is consistent with that of allozyme electrophoresis, particularly with regard to the relationship between the cryptic species M. georgesi and M. purvisi and to test the currently accepted phylogenetic hypothesis of monophyly of the genus with respect to Emydura and Elseya species. We also examined levels of mitochondrial divergence among 3 populations of the Endangered $M$. bellii to assess whether there is corroborating evidence in support of earlier suggestions that these be distinguished as separate species or subspecies. This study will assist in setting conservation priorities for $M$. bellii.

\section{MATERIALS AND METHODS}

Specimens of turtles within the genus Myuchelys (sensu Thomson \& Georges 2009) were collected from within their natural ranges by a combination of baited traps (after Legler 1960) or by hand with the aid of mask and fins. The focal species, $M$. bellii (Gray 1844), was collected from the headwaters of the Namoi and Gwydir Rivers of New South Wales (NSW) and Border Rivers of Queensland (Qld), each draining into the Darling River of the Murray-Darling drainage basin. Other species were M. purvisi (Wells \& Wellington 1985) restricted to the Manning River of coastal NSW, M. georgesi (Cann 1997) restricted to the Bellingen River of coastal NSW and M. latisternum (Gray 1867) from the rivers draining northeast NSW. Three species were chosen a priori as a nested series of outgroup taxa: the distantly related longnecked species Chelodina rugosa (Ogilby 1890) from rivers draining the Gulf of Carpentaria (Qld), Elseya dentata (Gray 1863) from the Roper River in the Northern Territory (NT), a close relative to Myuchelys genus, and Emydura macquarii (Gray 1830, 1857) from the Murray River of Victoria (Vic), a species currently positioned taxonomically between Elseya and Myuchelys (Thomson \& Georges 2009).

Skin samples $\left(2-5 \mathrm{~mm}^{2}\right)$ were taken from the neck or hind leg in the case of Myuchelys bellii using a sharp sterilised scalpel or surgical scissors. The samples were preserved in $95 \%$ ethanol and transported to the University of Canberra where they were stored at $-20^{\circ} \mathrm{C}$. Tissue samples for other species were obtained from the wildlife tissue collection of the Institute for Applied Ecology at the University of Canberra, and comprised skin, liver or blood snap frozen in liquid nitrogen and stored at $-80^{\circ} \mathrm{C}$.

Total genomic DNA was extracted by salt extraction (after Miller et al. 1988, modified by FitzSimmons et al. 1995). Sub-samples of skin were digested overnight at $55^{\circ} \mathrm{C}$ in $300 \mu$ of buffer (40 mmol Tris, 20 mmol EDTA, $100 \mathrm{mmol} \mathrm{NaCl}$ ), $20 \mu \mathrm{l}$ of $10 \%$ SDS and $10 \mu \mathrm{l}$ of $10 \mathrm{mg} \mathrm{ml}^{-1}$ Proteinase K. DNA was salt extracted and precipitated with $150 \mu \mathrm{l}$ of $7.5 \mathrm{~mol}$ ammonium acetate and $1 \mathrm{ml}$ of $100 \%$ ethanol, washed with $70 \%$ ethanol before being resuspended in $50 \mu \mathrm{l}$ of water. A $4 \mu \mathrm{l}$ subsample of each extraction was run out on a gel to confirm the success of the extraction.

PCR of the mitochondrial ND4 region (coding) used primers ND4F (5'-CAC CTA TGA CTA CCA AAA GCT CAT GTA GAA GC-3') (Arevalo et al. 1994) and ND4intR (5'-AGG TGT TCT CGT CTT TG-3') (Alacs 2008 ) to yield a $640 \mathrm{bp}$ DNA fragment. PCR of the mitochondrial control region (non-coding) used primers TCR500 and EMYTHR TCR500 (5'-CAC CAC CCT CCT GAA ATA CTC-3') and PS15841 (5'CMT TGG YCT TGT AAA CC-3') (Engstrom et al. 2004 ) to yield a $450 \mathrm{bp}$ DNA fragment. PCR products ( $50 \mu \mathrm{l}$ of each sample) were precipitated with $50 \mu \mathrm{l}$ of $20 \%$ polyethylene glycol, washed with $80 \%$ ethanol and re-suspended in $13 \mu \mathrm{l}$ of water. The cleanup PCR products were packaged and sent to a commercial service for sequencing. Sequence data were edited using SEQUENCHER V 4.1.4 (Genes Code) and aligned using CLUSTAL X (Thompson et al. 1997), with final alignment by eye.

All sequences were visually examined to eliminate the possibility that they might be nuclear mitochondrial DNA (numts). The chromatograms were clean, lacking ambiguous base signals that might have otherwise indicated presence of both mitochondrial and nuclear paralogues in a single PCR product. The coding section of the ND4 sequences for the 7 taxa were checked for the presence of premature stop codons (Coin \& Durbin 2004, Hay et al. 2004, Lerat \& Ochman 2005), and none was found. The amplified DNA of all 7 taxa were aligned to a known complete ND4 genome from a distantly related tortoise, Geochelone pardalis (GenBank accession number DQ080041; Parham et al. 2006). The nucleotides for each sequence, including for G. pardalis, were converted to amino acids prior to alignment. All amplified sequences were confirmed to be ND4 gene segments prior to phylogenetic analysis. While none of these approaches eliminate the possibility of nuclear 
paralogues of mitochondrial sequences in our data, they at least reduce the probability.

Phylogenies for ND4 and the control region sequences were generated using maximum parsimony (MP) and maximum likelihood (ML) as implemented in PAUP V4.0b10 (Swofford 2002). For the ML analyses, the HKY85+G (Hasegawa et al. 1985) model of sequence evolution was chosen using ModelTest (Posada \& Crandall 1998) prior to being implemented in Mega (Tamura et al. 2007). Trees were rooted using a nested series of outgroups. The most distantly related taxon Chelodina rugosa was chosen on the basis of the previous analyses of Georges \& Adams $(1992,1996)$. This confirmed the use of Elseya dentata as a closer outgroup taxon. Emydura macquarii was not found to be a suitable outgroup taxon. Robustness of the resultant trees was determined using bootstrap analyses (2000 pseudoreplicates for MP and 1000 pseudoreplicates for $\mathrm{ML}$ ). Uncorrected $\mathrm{p}$ distances were calculated using Mega (Tamura et al. 2007). The specimens examined, including their collection locality and sample identification codes, are provided in Table 1.

\section{RESULTS}

The 640 bp ND4 sequences yielded 3 haplotypes for Myuchelys bellii, each differing by only a single base representing populations of the Namoi $(n=5)$, Gwydir $(\mathrm{n}=4)$ and Border Rivers $(\mathrm{n}=5)$, respectively. $M$. georgesi from the Bellinger River $(\mathrm{n}=5)$ and $M$. purvisi from the Manning River $(\mathrm{n}=5)$ each yielded a single haplotype. $M$. latisternum from the Tweed River ( $\mathrm{n}=1)$ and Richmond River $(\mathrm{n}=1)$ had haplo-

Table 1. Myuchelys spp. and presumptive outgroups Chelodina rugosa, Elseya dentata and Emydura macquarii. Specimens examined for each species of Australian freshwater turtle, including details of the stream, locality and number of samples used in the analysis. AM: Australian Museum; UC: University of Canberra Wildlife Tissue Collection; Qld: Queensland; NSW: New South Wales; NT: Northern Territory. Drainage basin names are those of Australia's River Basins 1997 available from Geoscience Australia. Species names follow those of Georges \& Thomson (2010)

\begin{tabular}{|c|c|c|c|c|c|}
\hline Species & Stream & Location & $\begin{array}{c}\text { Unique } \\
\text { haplotypes }\end{array}$ & $\begin{array}{l}\text { No. } \\
\text { specimens }\end{array}$ & $\begin{array}{l}\text { Sample } \\
\text { identification }\end{array}$ \\
\hline \multirow[t]{3}{*}{$\begin{array}{l}\text { Myuchelys } \\
\text { bellii }\end{array}$} & $\begin{array}{l}\text { Border Rivers } \\
\text { (Qld) }\end{array}$ & $\begin{array}{l}28^{\circ} 50^{\prime} 55^{\prime \prime} \mathrm{S}, 151^{\circ} 57^{\prime} 56^{\prime \prime} \mathrm{E} \\
28^{\circ} 50^{\prime} 31^{\prime \prime} \mathrm{S}, 151^{\circ} 53^{\prime} 48^{\prime \prime} \mathrm{E} \\
28^{\circ} 50^{\prime} 46^{\prime \prime} \mathrm{S}, 151^{\circ} 56^{\prime} 24^{\prime \prime} \mathrm{E}\end{array}$ & 1 & $\begin{array}{l}1 \\
2 \\
2\end{array}$ & $\begin{array}{l}\text { UC Q19132 } \\
\text { UC Q19136-7 } \\
\text { UC Q19138, Q19146 }\end{array}$ \\
\hline & $\begin{array}{l}\text { Namoi River } \\
\text { (NSW) }\end{array}$ & $\begin{array}{l}30^{\circ} 56^{\prime} 24^{\prime \prime} \mathrm{S}, 151^{\circ} 20^{\prime} 30^{\prime \prime} \mathrm{E} \\
30^{\circ} 29^{\prime} 42^{\prime \prime} \mathrm{S}, 151^{\circ} 18^{\prime} 4^{\prime \prime} \mathrm{E} \\
30^{\circ} 41^{\prime} 8^{\prime \prime} \mathrm{S}, \quad 151^{\circ} 7^{\prime} 16^{\prime \prime} \mathrm{E}\end{array}$ & 1 & $\begin{array}{l}3 \\
1 \\
1\end{array}$ & $\begin{array}{l}\text { UC AA018919-21 } \\
\text { UC AA042492 } \\
\text { UC AA018922 }\end{array}$ \\
\hline & $\begin{array}{l}\text { Gwydir River } \\
\text { (NSW) }\end{array}$ & $\begin{array}{l}30^{\circ} 28^{\prime} 5^{\prime \prime} \mathrm{S}, \quad 151^{\circ} 19^{\prime} 40^{\prime \prime} \mathrm{E} \\
30^{\circ} 31^{\prime} 31^{\prime \prime} \mathrm{S}, 151^{\circ} 7^{\prime} 12^{\prime \prime} \mathrm{E}\end{array}$ & 1 & $\begin{array}{l}2 \\
2\end{array}$ & $\begin{array}{l}\text { UC AA018917-8 } \\
\text { UC AA018915, AA018922 }\end{array}$ \\
\hline M. georgesi & $\begin{array}{l}\text { Bellinger River } \\
\text { (NSW) }\end{array}$ & $30^{\circ} 27^{\prime} 40^{\prime \prime} \mathrm{S}, 152^{\circ} 37^{\prime} 19^{\prime \prime} \mathrm{E}$ & 1 & 5 & $\begin{array}{l}\text { UC } 131 \text { (AM R120965), UC } 147 \text { (AM } \\
\text { R123043) UC } 152 \text { (AM R123044), } \\
\text { UC } 154 \text { (AM R123045), UC } 159 \\
\text { (AM R123046) }\end{array}$ \\
\hline M. purvisi & $\begin{array}{l}\text { Manning River } \\
(\mathrm{NSW})^{\mathrm{a}}\end{array}$ & $31^{\circ} 44^{\prime} 60^{\prime \prime} \mathrm{S}, 151^{\circ} 51^{\prime} 0^{\prime \prime} \mathrm{E}$ & 2 & 5 & $\begin{array}{l}\text { UC } 129 \text { (AM R120966), UC } 130 \text { (AM } \\
\text { R120967), UC } 138 \text { (AM R123041), } \\
\text { UC } 140 \text { (AM R123040), UC } 153 \\
\text { (AM R123042) }\end{array}$ \\
\hline \multirow[t]{2}{*}{ M. latisternum } & $\begin{array}{l}\text { Richmond River } \\
\text { (NSW) }\end{array}$ & $28^{\circ} 50^{\prime} 59^{\prime \prime} \mathrm{S}, 153^{\circ} 16^{\prime} 1^{\prime \prime} \mathrm{E}$ & 1 & 1 & UC 181 (AM R123037) \\
\hline & $\begin{array}{l}\text { Tweed River } \\
\text { (Qld) }\end{array}$ & $28^{\circ} 22^{\prime} 0^{\prime \prime} \mathrm{S}, \quad 153^{\circ} 22^{\prime} 1^{\prime \prime} \mathrm{E}$ & 1 & 1 & UC 127 (AM R120997) \\
\hline $\begin{array}{l}\text { Emydura } \\
\text { macquarii }\end{array}$ & $\begin{array}{l}\text { Murray-Riverina } \\
\text { (NSW) }\end{array}$ & $36^{\circ} 6^{\prime} 49^{\prime \prime} \mathrm{S}, \quad 146^{\circ} 57^{\prime} 53^{\prime \prime} \mathrm{E}$ & 1 & 1 & UC 120 (R120954) \\
\hline $\begin{array}{l}\text { Elseya } \\
\text { dentata }\end{array}$ & $\begin{array}{l}\text { Roper River } \\
\text { (NT) }\end{array}$ & $14^{\circ} 43^{\prime} 50^{\prime \prime} \mathrm{S}, 134^{\circ} 30^{\prime} 14^{\prime \prime} \mathrm{E}$ & 1 & 1 & UC AA10883 \\
\hline \multirow[t]{2}{*}{$\begin{array}{l}\text { Chelodina } \\
\text { rugosa }\end{array}$} & $\begin{array}{l}\text { Nicholson River } \\
\text { (NT) }\end{array}$ & $17^{\circ} 58^{\prime} 37^{\prime \prime} \mathrm{S}, 139^{\circ} 45^{\prime} 7^{\prime \prime} \mathrm{E}$ & 1 & 1 & UC AA20211 \\
\hline & $\begin{array}{l}\text { Mitchell River } \\
\text { (Qld) }\end{array}$ & $15^{\circ} 28^{\prime} 27^{\prime \prime} \mathrm{S}, 141^{\circ} 48^{\prime} 38^{\prime \prime} \mathrm{E}$ & 1 & 1 & UC AA20246 \\
\hline
\end{tabular}


types differing by $1 \mathrm{bp}$. The $450 \mathrm{bp}$ of the control region yielded 2 haplotypes for $M$. bellii differing by only a single base, and representing populations of the Namoi-Gwydir and Border Rivers, respectively. M. georgesi from the Bellinger River $(\mathrm{n}=5)$ yielded a single haplotype, and M. purvisi from the Manning River $(\mathrm{n}=5$ ) yielded 2 haplotypes differing by only 1 bp. Again M. latisternum from the Tweed and Richmond Rivers had different haplotypes, differing by 3 bp. In total, 8 unique haplotypes (concatenated ND4 and control region mtDNA fragments) were identified for species of Myuchelys, with 11 unique haplotypes across both ingroup ( $M$. bellii, $M$. georgesi, $M$. latisternum and $M$. purvisi) and outgroup taxa (Chelodina rugosa, Elseya dentata and Emydura macquarii). A matrix of uncorrected genetic $\mathrm{p}$ distances for all pairs of taxa, including outgroups, combining the ND4 and control region sequences, is presented in Table 1 (GenBank accession nos.: JN006511-JN006521).

The haplotype phylogeny based on the combined ND4 and control region mtDNA sequences (Fig. 2) revealed Myuchelys bellii as the sister taxon to $M$. latisternum, an arrangement with very strong bootstrap support from both the MP (99\%) and ML (97\%) analyses. M. georgesi and $M$. purvisi, although once a cryptic species pair, are not sister taxa; rather, $M$. georgesi is sister to the $M$. bellii/latisternum clade (MP 90\%, ML 71\%). Genetic distance between $M$. georgesi and $M$. purvisi was $13.5 \%$ (Table 2), as great as between any 2 of the ingroup taxa. An unexpected result was the inclusion of 1 of the 3 nested outgroup taxa, Emydura macquarii, among the ingroup as sister to $M$. georgesi (Fig. 2). Indeed, the genetic distances between E. macquarii and the species of Myuchelys ranged from 7.9 to $9.6 \%$, compared to 13.0 to $13.7 \%$ for $M$. purvisi (Table 2). The currently accepted taxonomy would have $E$. macquarii as sister to Elseya dentata and outside the Myuchelys radiation (Georges \& Adams 1992, 1996, Thomson \& Georges 2009, Georges \& Thomson 2010). For this arrangement to be consistent with our data, an additional 28 base changes are required in addition to the 546 base changes required to explain the most parsimonious topology (Swofford 2002) (Fig. 2A). In likelihood terms, the currently accepted arrangement had a log likelihood ratio of 11.2 when compared with the tree of maximum likelihood (Fig. 2B). A permutation test of the difference between the 2 topologies $\left(1 \times 10^{6}\right.$ replications $)$ indicated that this difference was highly significant $(\mathrm{p}<$ $0.00013)$. We thus interpret the finding of $E$. macquarii within the Myuchelys radiation as a real feature of the ND4-control region mtDNA phylogeny.

\section{DISCUSSION}

Multi-locus allozyme data on the delineation of Australian chelid species boundaries (sensu Georges \& Adams, 1992, 1996) indicated that populations of
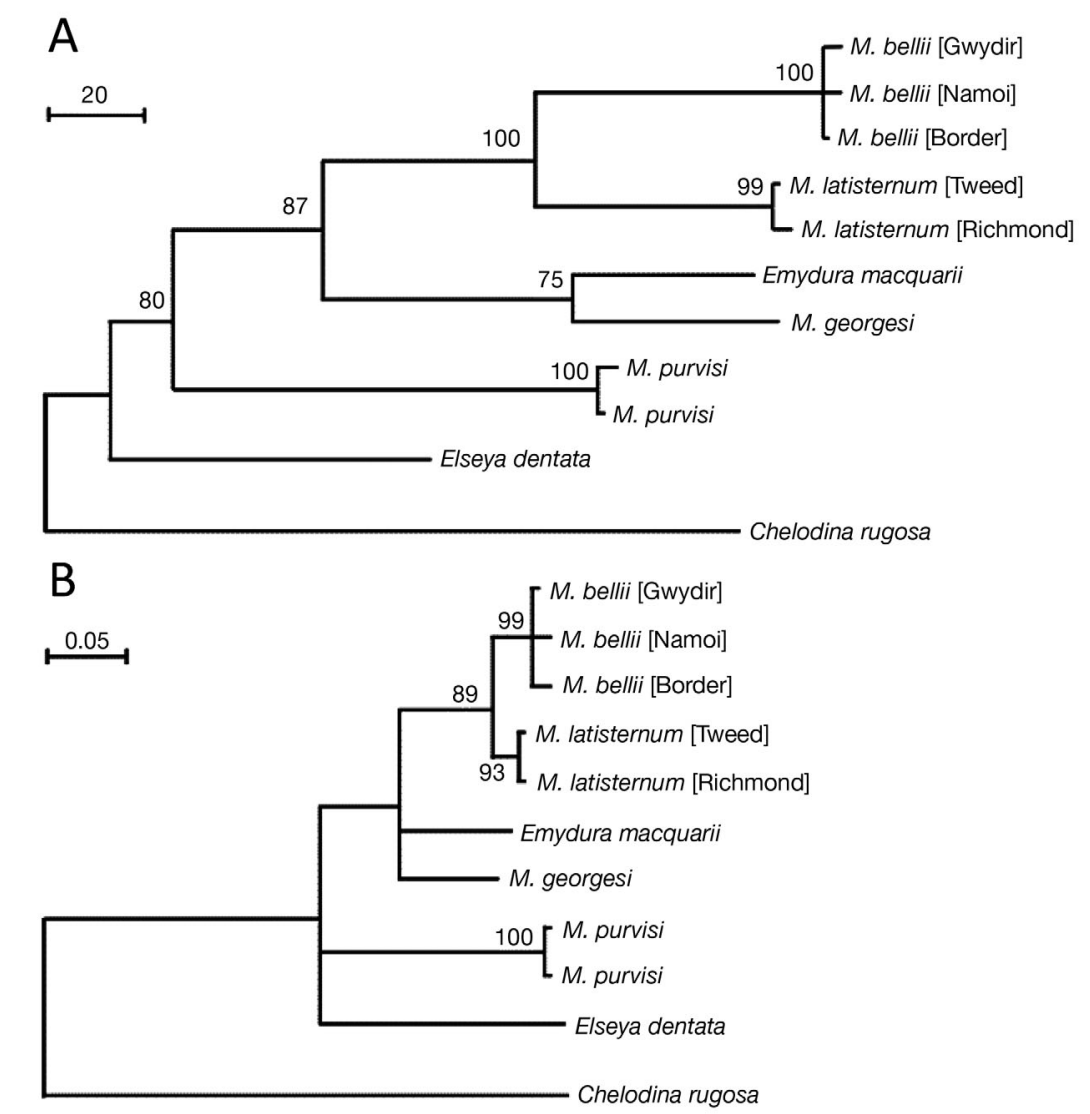

Fig. 2. Myuchelys spp. and presumptive outgroups Chelodina rugosa, Elseya dentata and Emydura macquarii. (A) Maximum parsimony and (B) maximum likelihood trees generated using PAUP* (Swofford 2002) with concatenated sequences of ND4 (640 bp) and control region mtDNA (450 bp). Alignment gaps were treated as deletions, yielding 971 characters of which 193 were parsimony informative. Branch lengths drawn proportional to maximum likelihood estimates of genetic divergence. Drainage basin names are provided in brackets where multiple populations of the same species were sampled (see Table 1) 
Table 2. Myuchelys spp. and presumptive outgroups Chelodina rugosa, Elseya dentata and Emydura macquarii. Uncorrected $\mathrm{p}$ distances between unique haplotypes of species. Upper matrix: raw p distances; lower matrix: percentage distances $(\mathrm{N}=$ 971 bp after gap removal). Mybel: Myuchelys bellii; Mylat: M. latisternum; Mygeo: M. georgesi; Mypur: M. purvisi; Emmac: Emydura macquarii; Elden: Elseya dentata; Chrug: Chelodina rugosa. Drainage basin names are provided in brackets where multiple populations of the same species were sampled (see Table 1)

\begin{tabular}{|c|c|c|c|c|c|c|c|c|c|c|c|}
\hline & $\begin{array}{l}\text { Mybel } \\
\text { (Border) }\end{array}$ & $\begin{array}{l}\text { Mybel } \\
\text { (Gwydir) }\end{array}$ & $\begin{array}{c}\text { Mybel } \\
\text { (Namoi) }\end{array}$ & $\begin{array}{c}\text { Mylat } \\
\text { (Richmond) }\end{array}$ & $\begin{array}{l}\text { Mylat } \\
\text { (Tweed) }\end{array}$ & Mygeo & Mypur & Mypur & Emmac & Elden & Chrug \\
\hline Mybel(Border) & 0 & 2 & 3 & 35 & 36 & 89 & 131 & 130 & 92 & 133 & 221 \\
\hline Mybel(Gwydir) & 0.002 & 0 & 1 & 34 & 35 & 89 & 132 & 131 & 92 & 132 & 220 \\
\hline Mybel(Namoi) & 0.003 & 0.001 & 0 & 35 & 36 & 90 & 133 & 132 & 93 & 131 & 221 \\
\hline Mylat(Richmond) & 0.036 & 0.035 & 0.036 & 0 & 4 & 85 & 128 & 127 & 89 & 134 & 212 \\
\hline Mylat(Tweed) & 0.037 & 0.036 & 0.037 & 0.004 & 0 & 84 & 127 & 126 & 89 & 130 & 210 \\
\hline Mygeo & 0.092 & 0.092 & 0.093 & 0.088 & 0.087 & 0 & 131 & 130 & 77 & 143 & 215 \\
\hline Mypur & 0.135 & 0.136 & 0.137 & 0.132 & 0.131 & 0.135 & 0 & 1 & 135 & 149 & 235 \\
\hline Mypur & 0.134 & 0.135 & 0.136 & 0.131 & 0.13 & 0.134 & 0.001 & 0 & 134 & 148 & 234 \\
\hline Emmac & 0.095 & 0.095 & 0.096 & 0.092 & 0.092 & 0.079 & 0.139 & 0.138 & 0 & 132 & 226 \\
\hline Elden & 0.137 & 0.136 & 0.135 & 0.138 & 0.134 & 0.147 & 0.153 & 0.152 & 0.136 & 0 & 225 \\
\hline Chrug & 0.228 & 0.227 & 0.228 & 0.218 & 0.216 & 0.221 & 0.242 & 0.241 & 0.233 & 0.232 & 0 \\
\hline
\end{tabular}

Myuchelys bellii from the Namoi and Gwydir Rivers could be diagnosable as a distinct species, but they did not have samples from the Border Rivers. Since that allozyme study (George \& Adams 1992), the Bald Rock Creek (Qld) populations have been identified as distinct morphologically from those of the Namoi and Gwydir Rivers (NSW), and separate species status has been proposed (Cann 1998, Wells 2002). Such distinction failed to be sustained under more rigorous morphological analysis of the 3 populations of the Endangered M. bellii (Fielder 2010). Additionally, the level of genetic divergence between the 3 isolated populations is equivalent to those observed between populations of $M$. latisternum from adjacent drainages (Table 1). These exceptionally low levels of mtDNA in $M$. bellii populations suggest that they should be viewed as a single taxon. Consequently, the proposition that the population in Girraween National Park (Qld) is a separate species or subspecies from those in the Gwydir and Namoi Rivers draws no support from our data. Turtles from the 3 populations occupy a single drainage basin, and although isolated to some degree, it is possible that divergence is impeded by low-frequency genetic exchange between these populations. There is at least 1 anecdotal report from the 1970s of $M$. bellii from the Macquarie Marshes (100 km downstream of its established range and below the confluence of the waters of the Namoi and Gwydir Rivers, Fig. 1), which gives credence to the proposition that such low-level exchange is ongoing. Alternatively, the extant populations of $M$. bellii might represent the outcome of recent range contraction. Recent surveys (Cann 1998, Fielder 2010, this study) looking for $M$. bellii in stream segments between known populations in the Namoi, Gwydir and the Girraween National Park populations failed to detect $M$. bellii movements. With so few data, there is no evidence whether they are isolated and do have some (minimal) gene flow, or whether they in fact have high levels of gene flow, or whether they have diverged very recently (with or without gene flow) exhibiting almost no genetic differentiation. Further investigation is required to categorically rule out these possibilities.

Consistent with earlier studies (Georges \& Adams 1992, 1996), our mtDNA phylogeny establishes Myuchelys bellii west of the Great Dividing Range and M. latisternum east of the Great Dividing Range and across the north of Australia as sister taxa. There are associated morphological similarities that are interpreted as synapomorphies (Fielder 2010), including moderately to deeply serrated shell margins, dorso-ventrally depressed carapace, broad head with furrowed head shield in aged adults and pronounced neck tubercles. Also consistent with earlier studies is the separation in the phylogeny of $M$. purvisi and $M$. georgesi, which share external morphological characters (Cann 1998), yet are not sister species. Indeed a $13.5 \%$ divergence in the present mtDNA phylogeny corroborates earlier molecular studies of a $20 \%$ divergence in fixed allelic differences (Georges \& Adams 1996). Their common ancestor has all 4 species of Myuchelys among its descendants. This is either a remarkable case of character convergence in allopatry between $M$. georgesi of the Bellinger River and M. purvisi of the Manning River, or these 2 species have preserved a 
shared suite of plesiomorphic (retained) characters over many millions of years. This latter interpretation seems more likely, and if correct opens a unique window on the morphology of the ancestor of the sawshelled turtle radiation. This study demonstrates that genetic and morphological divergence can be uncoupled, leading to potentially conflicting interpretations of relationships among taxa if based solely on morphological data.

The observed placement of Emydura macquarii in the mtDNA phylogeny is a major departure from the currently accepted phylogeny and associated taxonomy (Georges \& Thomson 2010). E. macquarii would be expected to be sister to Elseya dentata (McDowell 1983, Georges \& Adams 1996), and outside the Myuchelys radiation (Georges \& Adams 1992). This group has had a long and confused history. The genus Elseya was originally erected for E. dentata (the type species) and $M$. latisternum (formerly E. latisternum) (Gray 1867, 1872). Boulenger (1889) redefined the genus on the basis of a longitudinal shearing ridge on the maxillary triturating surface, the alveolar ridge, present only in E. dentata. E. latisternum and E. novaeguineae were placed in the genus Emydura. Furthermore, Gaffney (1977) was unable to distinguish the genera Elseya and Emydura using cranial features (though E. latisternum was not available to him), and later Gaffney (1979) used the 2 in synonymy. McDowell (1983) interpreted a wider range of morphological characters to indicate that the closest relative of $E$. dentata is E. australis (including E. krefftii and E. subglobosa) and not E. latisternum. He concluded that 'the generic recognition of Elseya seems unwarranted' and synonymised Elseya and Emydura. In contrast, Legler \& Cann (1980) considered that morphological similarities between species in the 2 genera are sufficient to indicate a common ancestry, but not to warrant lumping the genera. The matter was resolved when Georges \& Adams (1992) demonstrated, using allozyme electrophoresis, that the genus Elseya was paraphyletic, with Emydura coming between clades referred to today as Elseya and Myuchelys (Thomson \& Georges 2009). Unlike Gaffney (1979) and McDowell (1983), Georges \& Adams (1992) resolved the paraphyly by recommending a new genus for E. latisternum and its relatives (now Myuchelys). At the time, it was noted that the nearest living relative to $E$. dentata was Emydura 'australis' (including E. krefftii and E. subglobosa; McDowell 1983) and not E. latisternum, a result supported by the allozyme data (Georges \& Adams 1992, 1996).

Clearly, the outcome of the mtDNA studies further complicates the matter. In terms of the mtDNA sequences we examined, Emydura macquarii and Myuchelys georgesi are closer to each other than either is to Elseya dentata, and this is reflected by a sister relationship between the former 2 in the mtDNA phylogeny. If verified, this finding would require the generic names and definitions to be revisited, either by synonymising genera, erecting yet another monotypic genus, this time for M. purvisi, or recognising and accepting the paraphyly and retaining the existing nomenclature. We do not propose to take this action here because our data are based on mitochondrial DNA, and potentially subject to the factors that can affect any studies based on a single locus. Hybridisation between Australian chelid turtle species is widespread and there is at least 1 instance of hybridisation between $M$. latisternum and E. macquarii (C. Limpus pers. comm.). The possibility of historical horizontal transfer of mitochondrial genomes requires that this finding be presented as a hypothesis for testing in future with multilocus data, molecular or morphological.

Notwithstanding the taxonomic uncertainties, Myuchelys is a phylogenetically distinct group of chelids emerging as a priority for conservation management within the Australasian fauna. Three out of the 4 species have extremely restricted distributions, being restricted to headwaters of single drainages which makes them particularly vulnerable to ongoing threatening processes within their catchments. $M$. bellii is of particular concern. The 3 major populations of $M$. bellii are distributed across 2 jurisdictions (Qld and NSW) and primarily along stretches of river in private hands. The small Qld population $(<400$ individuals, Fielder 2010) from Bald Rock Creek ( $<10 \mathrm{~km}$ reach) has experienced significant habitat modification through mechanical removal of instream boulders and riparian vegetation and loss through impoundment of a major permanent natural waterhole. Whilst the Qld population appears healthy and stable, these threatening processes and the small population size make the question of its species status more important from a conservation point of view. A significant proportion of the restricted, but locally abundant, Namoi and Gwydir turtle populations are suffering serious eye damage and blindness from eye cataracts from unknown causes (Cann 1998). Our study has shown little evidence of divergence of the 3 populations of $M$. bellii, and as such, they should be managed as a single operational taxonomic unit. This will involve additional attention both off and on reserve to protecting the remaining refugial habitat in the headwaters of the Namoi, Gwydir and Border Rivers of the Murray-Darling 
catchment, as well as attention to the corridors that enable free and effective passage between these when conditions allow. The persistence and quality of wetlands like the Macquarie Marshes may prove pivotal in the long-term persistence of the 3 'isolated' populations of the Endangered $M$. bellii.

Acknowledgements. This paper arose from the $\mathrm{PhD}$ project of D.F. on the population ecology, ecophysiology, phylogenetics and taxonomy of the western saw-shelled turtle Myuchelys bellii from the Murray-Darling basin of Australia. We thank K. Hodges for assistance in aspects of the laboratory analysis and comments on an earlier draft. We are also grateful to the many volunteers who provided assistance in the field. This study was supported by a grant from the University of New England, with additional logistic support and laboratory facilities provided by the Institute for Applied Ecology at University of Canberra. The Queensland Department of Environment and Resource Management provided housing and staff support for the fieldwork undertaken in Girraween National Park, Border Rivers.

\section{LITERATURE CITED}

Alacs EA (2008) Forensics, phylogeography and population genetics: a case study using the northern snake-necked turtle, Chelodina rugosa. $\mathrm{PhD}$ thesis, University of Canberra

Anderson BJ, Armsworth PR, Eigenbrod F, Thomas CD and others (2009) Spatial covariance between biodiversity and other ecosystem service priorities. J Appl Ecol 46:888-896

Arevalo E, Davis S, Sites J (1994) Mitochondrial DNA sequence divergence and phylogenetic relationships among eight chromosome races of the Sceloporus grammicus complex (Phrynopsomatidae) in Mexico. Syst Biol 43:387-418

Baumgärtner S (2007) The insurance value of biodiversity in the provision of ecosystem services. Nat Res Model 20: 87-126

Boulenger GA (1889) Catalogue of the chelonians, rhynchocephalians, and crocodiles in the British Museum (Natural History). British Museum of Natural History, London

- Cairns J (1997) Protecting the delivery of ecosystem services. Ecosyst Health 3:185-194

Cann J (1997) Georges short-necked turtle. Monitor 9: $18-23,31,32$

Cann J (1998) Australian freshwater turtles. Beaumont Publishing, Singapore

> Coin L, Durbin R (2004) Improved techniques for the identification of pseudogenes. Bioinformatics 20(Suppl 1):i94-100

Commonwealth of Australia (1999) Environment Protection and Biodiversity Conservation (EPBC) Act 1999. Department of the Attorney-General, Canberra

Engstrom TN, Shaffer HB, McCord WP (2002) Phylogenetic diversity of endangered and critically endangered southeast Asian softshell turtles (Trionychidae: Chitra). Biol Conserv 104:173-179

Engstrom TN, Shaffer HB, McCord WP (2004) Multiple data sets, high homoplasy, and the phylogeny of softshell turtles (Testudines: Trionychidae). Syst Biol 53:693-710

Faith DP (1992) Conservation evaluation and phylogenetic diversity. Biol Conserv 61:1-10
Fielder DP (2010) Population ecology, ecophysiology, phylogenetics and taxonomy of the threatened western sawshelled turtle, Myuchelys bellii, from the Murray-Darling Basin of Australia. PhD dissertation, University of New England, Armidale

FitzSimmons NN, Moritz C, Moore SS (1995) Conservation and dynamics of microsatellite loci over 300 million years of marine turtle evolution. Mol Biol Evol 12: $432-440$

> Fritz U, Fattizzo T, Guicking D, Tripepi S and others (2005) A new cryptic species of pond turtle from southern Italy, the hottest spot in the range of the genus Emys (Reptilia, Testudines, Emydidae). Zool Scr 34:351-371

> Fritz U, d'Angelo S, Pennisi MG (2006) Variation of Sicilian pond turtles, Emys trinacris: What makes a species cryptic? Amphib-Reptilia 27:513-529

Fritz U, Guicking D, Auer M, Sommer RS, Wink M, Hundsdorfer AK (2008) Diversity of the Southeast Asian leaf turtle genus Cyclemys: how many leaves on its tree of life? Zool Scr 37:367-390

Gaffney ES (1977) The side-necked turtle family Chelidae: a theory of relationships using shared derived characters. Am Mus Novit 2620:1-28

Gaffney ES (1979) Fossil chelid turtles of Australia. Am Mus Novit 2681:1-23

Georges A, Adams M (1992) A phylogeny for Australian chelid turtles based on allozyme electrophoresis. Aust J Zool 40:453-476

Georges A, Adams M (1996) Electrophoretic delineation of species boundaries within the short-necked freshwater turtles of Australia (Testudines: Chelidae). Zool J Linn Soc 118:241-260

Georges A, Thomson S (2010) Diversity of Australasian freshwater turtles, with an annotated synonymy and keys to species. Zootaxa 2496:1-37

Georges A, Spencer RJ, Welsh M, Shaffer HB, Walsh R, Zhang X (2011) Application of the precautionary principle to taxa of uncertain status - the case of the Bellinger River Turtle. Endang Species Res 14:127-134

Gray JE (1830) A synopsis of the species of the class Reptilia. In: Griffith E (ed) The animal kingdom arranged in conformity with its organization by the Baron Cuvier. Whittaker, Treacher \& Co., London, p 1-110

Gray JE (1844) Catalogue of the tortoises, crocodiles and amphibianians in the collection of the British Museum. Edward Newman, London

Gray JE (1857) Description of a new species of Chelodina from Australia. Proc Zool Soc Lond 1856:369-371

Gray JE (1863) On the species of Chelymys from Australia, with the description of a new species. Ann Mag Nat Hist 12:98-99, 246

Gray JE (1867) Description of a new Australian tortoise (Elseya latisternum). Ann Mag Nat Hist 20:43-45

Gray JE (1872) On the genus Chelymys and its allies from Australia. Proc Zool Soc Lond 1872:504-514

Hasegawa H, Kishino $H$, Yano $T$ (1985) Dating the human-ape split by a molecular clock by mitochondrial DNA. J Mol Evol 22:160-174

Hay JM, Sarre SD, Daugherty CH (2004) Nuclear mitochondrial pseudogenes as molecular outgroups for phylogenetically isolated taxa: a case study in Sphenodon. Heredity 93:468-475

IUCN (International Union for Conservation of Nature) (2011) IUCN Red List of Threatened Species, Version 2011.1. Available at www.iucnredlist.org 
Legler J (1960) A simple and inexpensive device for trapping aquatic turtles. Proc Utah Acad Sci Arts Lett 37: 63-66

Legler J, Cann J (1980) A new genus and species of chelid turtle from Queensland, Australia. Contrib Sci 324:1-18

Lerat E, Ochman H (2005) Recognizing the pseudogenes in bacterial genomes. Nucleic Acids Res 33:3125-3132

McDowell SB (1983) The genus Emydura (Testudines: Chelidae) in New Guinea with notes on the penial morphology of Pleurodira. In: Rhodin A, Miyata K (eds) Advances in herpetology and evolutionary biology: essays in honour of Ernest E. Williams. Museum of Comparative Zoology, Harvard University, Cambridge, MA, p 169-189

Miller SA, Dykes DD, Polesky HF (1988) A simple salting out procedure for extracting DNA from human nucleated cells. Nucleic Acids Res 16:1215

Moritz C (1995) Uses of molecular phylogenies for conservation. Philos Trans R Soc Lond B Biol Sci 349:113-118

New South Wales (1995) Threatened species conservation act 1995. The Office of Environment and Heritage, Sydney

Ogilby JD (1890) Description of a new Australian tortoise. Rec Aust Mus 1:56-59

Parham JF, Macey JF, Papenfuss TJ, Feldman CR, Turkozan O, Polymeni R, Boore J (2006) The phylogeny of Mediterranean tortoises and their close relatives based on complete mitochondrial genome sequences from museum specimens. Mol Phylogenet Evol 38:50-64

Posada D, Crandall KA (1998) Modeltest: testing the model of DNA substitution. Bioinformatics 14:817-818
Roman J, Santhuff SD, Moler PE, Bowen BW (1999) Population structure and cryptic evolutionary units in the alligator snapping turtle. Conserv Biol 13:135-142

Salzman J (1998) Ecosystem services and the law. Conserv Biol 12:497-498

Stuart BL, Fritz U (2008) Historical DNA from museum type specimens clarifies diversity of Asian leaf turtles (Cyclemys). Biol J Linn Soc 94:131-141

Swofford DL (2002) PAUP*. Phylogenetic analysis using parsimony ( ${ }^{*}$ and other methods), Version 4 . Sinauer Associates, Sunderland, MA

- Tamura K, Dudley J, Nei M, Kumar S (2007) MEGA4: Molecular Evolutionary Genetics Analysis (MEGA) software version 4.0. Mol Biol Evol 24:1596-1599

Thompson JD, Gibson TJ, Plewniak F, Jeanmougin F, Higgins DG (1997) The ClustalX windows interface: flexible strategies for multiple sequence alignment aided by quality analysis tools. Nucleic Acids Res 25:4876-4882

Thomson S, Georges A (1996) Neural bones in Australian chelid turtles. Chelonian Conserv Biol 2:82-86

Thomson S, Georges A (2009) Myuchelys gen. nov. - a new genus for Elseya latisternum and related forms of Australian freshwater turtle (Testudines: Pleurodira: Chelidae). Zootaxa 2053:32-42

Wells RW (2002) Taxonomic notes on some Australian freshwater turtles of the genera Chelodina and Elseya (Reptilia: Chelidae). Aust Biodiv Rec 2002:1-30

Wells RW, Wellington CR (1985) A classification of the Amphibia and Reptilia of Australia. Aust J Herpetol Suppl Ser 1:1-61

Submitted: May 19, 2011; Accepted: January 14, 2012

Proofs received from author(s): March 13, 2012
Editorial responsibility: Steven Rossiter, London, UK 